University is to be commended for assisting in the publication of this useful study.

Washington, D. C.

Simon G. Hanson

Woytinsky, W. S. Earnings and Social Security in the United States. Pp. xiii, 260, plus separate appendix containing 25 tables. Washington: Committee on Social Security, Social Science Research Council, 1943. $\$ 2.50$.

In this study of statistical data Mr. Woytinsky makes a contribution of great value, both in respect of the conclusions reached regarding the inequalities of earnings as they bear upon social security, and in the techniques of analyzing such data. It may be predicted with confidence that in the development of a thoroughgoing system of social insurance, the technique of analysis here set out will become an important guide to sound evaluation of the bases of calculation of coverage and rates.

Publishing the twenty-five tables of the appendix separately and in larger format renders their use cumbersome and inconvenient, especially in the library.

The first chapter is devoted wholly to an explanation of the several procedures used in measuring inequalities. By the use of quartiles and deciles the author secures greater conciseness in his description of the dispersion in frequency distribution. By the device of mean deviation and mean difference, used in connection with the Lorenz curve, he secures a graphic definition of "inequality." To these approaches he applies the standard deviation method by computing deciles and quartiles for the several distributions of earnings, and compares these with the coefficient of variation of the means of the lowest and the highest.

The variance in methods of assembling data on numbers in the labor force, on earnings, and on taxable wages, is clearly brought out in the chapter on coverage of social security laws.

Employees and taxable wages in the national income pyramid are carefully processed through the technical gauge, but must necessarily rest upon presupposition, estimate, and some guesswork on the part of the administrative bodies responsible for the basic data.
Subject to these imperfections in the grist to be analyzed, the report takes up wages by sex, by race, by age, and by industry and occupation. Finally, there is a breakdown of wages by states.

The author makes an especially helpful contribution to the problem of social security programming in his thesis that over the last hundred years there has been a positive growth in the per capita wage of from 1 to 2 per cent per annum. Nor does he find any evidence of slackening in this rate of increase.

Unusually welcome to the student and the administrator will be the chapters on "Families as Beneficiaries of Old Age and Survivors Insurance," and "The Income Cycle of Families and Individuals." To the lawmaker and many another, Mr. Woytinsky's labor may present a terrifying display of accuracy; but the real builders of America's program of social security will hold it for constant reference.

\section{University of Michigan}

Robert W. KeLso

Straus, Nathan. The Seven Myths of Housing. Pp. xvi, 314, viii. New York: Alfred A. Knopf, 1944. \$2.75.

Mr. Straus, administrator of the United States Housing Authority during its first five years, has done a good job of pamphleteering. Like everyone in the housing business, he has found himself hearing always the same stock objections to public housing-based upon preconceptions or prejudices unrelieved by knowledge of facts. He has chosen seven of these shibboleths about which to focus his arguments: "There Are No Slums in My Town"; "Public Housing Does Not Clear Slums"; "The Government Should Buy Up the Slums"; "Public Housing Is Costly and Extravagant"; "Public Housing Does Not Rehouse Families from the Slums"; "The Slum Dweller Creates the Slums"; "Public Housing Injures Private Business and Threatens to Bankrupt the Country."

In the course of answering these slogans, Mr. Straus ranges broadly over "finance, economics, and sociology, not to mention architecture and city planning." The writing is simple, direct, and on the whole sweetly reasonable. Mr. Straus marshals 